\title{
Drought, Endurance and Climate Change 'Pioneers' Lived Experience in the Production of Rural Environmental Knowledge
}

\section{Deb ANDERSON}

...the future as history promises vast changes in all fields of life-both horrific possibilities and renewed hopes for humankind.

James O'Connor, The Meaning of Crisis ${ }^{1}$

This is a story of drought and climate change. The scene is a beguiling, semi-arid, inland Australian environment-one that has historically tested its inhabitants sorely through recurrent periods of drought and yet which, on reflection, responds well to human needs only insofar as its biophysical 'limits' are respected. The chief protagonist is a third-generation wheat farmer, whose spoken word brings country to life. And the plot-well, the plot unfurls in compelling, if confounding, ways.

The story commences in an all-too-familiar Australian saga of rural pioneering endurance-a boom-and-bust tale of backbreaking work, told with grim humour, of 'survival' through sporadic environmental extremes of drought. Anchored in that version of the past, the tale twists into a period of rural decline-of crisis 'so commonplace as to seem clichéd'-to depict an agro-industrial present clouded by economic uncertainty, amplified by prolonged drought and heightened by public debate on global climate change. ${ }^{2}$ Then, the plot thickens. The scene itself-of climate in the wheat-belt-shifts in ways that defy generations of lived experience. That final straw, so to speak, prompts a reflexive idealisation of history 
as the future: in the end, 'a new generation of pioneers', no less, will 'survive' by learning, within country, to 'pull back' ${ }^{3}$ A battler history of survival is rewritten with a message of ecological enlightenment.

As sociologist Barbara Adam wrote, 'tradition constitutes renewal at every moment of active reconstruction of past beliefs and commitments'. ${ }^{4}$ The story on which this article builds is a case in point. For in this interconnected narrative of humans and non-human nature 'going somewhere' (change, as environmental historian Donald Worster wrote, 'is never all there is in nature'; change 'leads somewhere, and it has a discernible direction, conventionally called Progress'), ${ }^{5}$ a parable of change brings with it a potent yearning for tradition. In turn, this prompts us as rural cultural researchers to take seriously the ways social and environmental risks are inextricably linked, to consider how and why human interpretations of disaster survive because of their usefulness in social and cultural systems. ${ }^{6}$ This story of drought and climate change is, therefore, even more a story about the making of stories-of storytelling as an expression of politics and time, and of how narrative fulfils the ideological needs of the moment.

Here, I draw upon research conducted with dryland farm communities in the Mallee wheat-belt of northwest Victoria from 2004 to 2007.7 This was a period of prolonged and recurrent droughts across southeast Australia. Much as droughts in Australia throughout the twentieth century were defined, consistently, as 'unexpectedly severe' in intensity or duration, ${ }^{8}$ in 2005 the nation was pronounced as suffering one of the worst droughts 'on record'-'in our history', stated the prime minister of the day. ${ }^{9}$ This was also a period of marked shift in public awareness of climate change. And, arguably, climate change projections have intensified debate over rural futures in Australia. ${ }^{10}$

Cultural engagement with climate is under constant renegotiation, however, as rural cultural research is apt to reveal. ${ }^{11}$ In the Mallee, I gathered oral histories with twenty-two people, life narratives that reveal the social and cultural dimensions of climate change. ${ }^{12}$ This article explores the multi-generational story of just one of those narratives to explore the history of ideas over time. Allowing space for the richness of detail that personal history offers, I have woven in elements of public history and analysis of the ways discourse on lived experience of climate defines and localises the identities of people and place in the production of 
environmental knowledge. In a sense this choice of research method was pragmatic, for discourse analysis is inherently political; it draws attention to the 'naturalising' function of discourse and the partial, contingent nature of knowledge on climate.

The concept of 'drought' to which I refer is a cultural term. Its primary connotations are less related to rainfall than to an overarching, mythic narrative of endurance. Insofar as droughts have punctuated Australian rural, regional and national histories, 'drought' has played a prominent role in the ongoing social construction of a 'harsh' and 'unpredictable' climate and in the mythologising of rural battlers, shaping foundational narratives of struggle and hope. ${ }^{13}$

In Victoria, the most intensively settled of Australian states, the Mallee in the northwest corner is the most sparsely populated region, with the lowest annual rainfall. ${ }^{14}$ In counterpoint, it is an ultra-productivist landscape-a region driven by forces of capital accumulation and engaged in ever-larger-scale industrial agriculture. The Victorian Mallee covers 39,300 square kilometres, or about onesixth of the state. ${ }^{15}$ Here, 'productive land' is considered 'the backbone of the economy' and about two thousand dryland farmers produce half Victoria's annual cereals crop, mostly wheat. ${ }^{16} \mathrm{Up}$ to one million hectares of this land put in dryland (rain-fed) crops each year, 'fed' on an annual 'average' of 200 to 500 millimetres of rain. ${ }^{17}$

Rural histories of the Mallee have represented spirited sagas of community struggle, endurance and hope in 'battling' a harsh climate. As environmental historian Tom Griffiths noted, the very word 'Mallee' became 'synonymous for heroic, even bloody-minded settlement'. 18 'Settled' from the mid-1800s with the establishment and subsequent collapse of pastoralism, the region was 'opened up' in the wholesale clearing of mallee forest and advance of dryland agriculture in the twentieth century. European occupation of the semi-arid Mallee has been narrated predominantly as an ongoing struggle on a frontier beset by environmental extremes, 'where coping with disastrous drought was part of the pioneer lifestyle'. ${ }^{19}$ Indeed, Mallee local histories form dedications to those pioneers, 'who succeeded because they never admitted defeat'. ${ }^{20}$ 
By contrast, the region's name derives from bushland considered to local Indigenous people as a supporter of life because of the water in mallee roots. ${ }^{21}$ The term 'mallee' is applied to eucalypts with a multi-stemmed habit; at the base of the stems is a woody structure or lignotuber that enables vegetative recovery after fire or other ecological stress. ${ }^{22}$ Invading Europeans deemed this bushland 'useless scrub' (a form of linguistic overkill, given in Australian English the term 'scrub' already denotes plant species liable to be constructed as of little value).23 Examples of contemporary Mallee tourism retain a fixation with the historical idea that, by extension, Mallee country was regarded as 'useless', ${ }^{24}$ but this (dis)regard speaks also of the force of colonial and productivist regimes since applied to it. Profoundly, inasmuch as 'Mallee' serves as a geographical marker, it is a placename founded upon absence. ${ }^{25}$ The Mallee marks the site of the very clearance of three-quarters of the original mallee lands. ${ }^{26}$ This is country where the mallee once grew. Today to gaze out across Mallee country is, on occasion, to see no mallee at all.

This district through here is never gonna make you a millionaire. You can always survive and that's what I like about it ... if you're patient and careful with it, you'll always survive.

Hubie Sheldon, organic broad-acre wheat farmer, $2005^{27}$

Sheep scatter in a wheat stubble-lined paddock, where someone's predecessors barely a century ago rolled and burned their block of mallee 'scrub'. Today in late summer it is a striking panorama, bold in magnitude yet subtle in colour. Sand hills slope away into a vast, silent expanse where converging plough-lines force the eye to traverse seemingly endless layers of white-beige, tan-orange and rust-pink. Skirting the fences at the edge of these vast cropping beds, hemmed in like remnant pockets of reprieve, are dark-olive thickets of native mallee bush.

It's thirty-nine degrees, it's February, and earlier in the day I had embarked on what felt like a drive to the end of Earth to reach Ngallo-pronounced 'ne-gallo' and meaning 'a spring'-a blip on the map of Victoria's semi-arid northwest. ${ }^{28}$ I admit, by the hour I reach Hubie Sheldon's farm my thoughts have turned to colonial engineer Alfred Kenyon's infamous account of 'sand, scrub and mallee below, the 
scorching sun and bright blue sky above, and not a sound to break the solemn silence'. ${ }^{29}$ Such words formed the narrative bed, so to speak, for his 1912 Story of the Mallee: a pioneering battle saga of men with 'hearts like lions', new methods and ever-more-advanced machines who would make this country 'profitably productive'. ${ }^{30}$ Unlike Kenyon with his oratory (or this researcher with her voice recorder), this is the place Sheldon calls home. Here on a Mallee broad-acre wheatsheep property is where Sheldon lives on his own and where he has spent most of his life, as did his father and mother before him, and his father's parents before them, having selected and cleared their block of sand and clay country in 1910. Across an old kitchen table, Sheldon begins his story.

\section{-Endurance}

That's the only reason why a person farms, I think, is because you're always thinking 'oh well, next year'll be alright'. And even if it's not, 'well, the next year will definitely be alright'...

Robert Pole, conventional broad-acre wheat farmer, $2005^{31}$

As they say, pride goeth before a fall ... Trees are dying, old established trees. You watch them as they start to lose their leaves ... and it's just that they've just given up ... The trees are a little bit like the older, established farmers. They seem to just, they'll take it and they take it and they take itand then they seem to, just, give up.

Andrea Hogan, newspaper editor/councillor, $2005^{32}$

Drought is a fact of life in the Mallee. And if you can't farm in a drought in the Mallee, well you have to get out. And that's a pretty cruel statement.

Greg Brown, conventional broad-acre wheat farmer/councillor, $2005^{33}$

Sheldon is the only member of his family left farming in the Mallee. As a child, he attended school in the nearby town of Murrayville. Yet it was farm labour and ideas on the educational value of farm familial work that governed discourse on childhood in Sheldon's history (and an ethics of work, as a means of knowing nature, prevailed in his contemporary farm life too). There was no television at home when he was young; anyway, he was expected to help out on the farm: 'The Old Man was always 
one to keep you busy ... You get out and you do something to earn your keep ... teaches you values early on.' ${ }^{34}$ He completed form five in 1977, after which he continued working at home on the farm. Then under his father's management, the property operated on a conventional three-year crop rotation with sheep, fallow (the repeated tilling of soil, in preparation for sowing) and crop. His father had died in 1985, aged seventy-five, from emphysema caused by inhaling dust while harvesting clover seed in the 1950s and '60s. But the Old Man (also a 'Hubie'), as well as 'a couple of uncles', retained prominent roles in Sheldon's discourse on settler Mallee history and climate. ${ }^{35}$ These men figured as primary storytellers in the tales of life on the land that he'd heard as a child, which centred upon periods in Ngallo district history of environmental calamity and market failure. Those stories began when the Sheldon property was still not 'properly developed':

What me parents have told me in regards to this district here ... They had the 1914 drought, which was a calm drought. Well there was one story, it didn't even blow enough wind to turn the windmills to get water for the horses, so they had to put a rope on the wheel and pull the wheel over and that was a job people had to do, pump water...

And then through the First World War era right through the early '20s, the district basically had a boom. There was good seasons one after the other, no hassles, and prices were good, everything looked rosy and then, the first bad erosion year was 1927-plus it was a droughty sort of a year, and as well as a rabbit plague, which as me father explained or showed me, he said when the rabbits were bad they could eat ten chain inside from a road ... 'It would be eaten down,' he said, 'like fallow' ... And he said everywhere you looked, there was dust. ${ }^{36}$

Rapid change to a semi-arid landscape had not come without consequence, and Sheldon's story of the Mallee began to form the shape of an evocative, if absurd, narrative of endurance, in which people survived physical and economic extremes:

And then 1928 was a good season and everyone thought 'oh well it's gone'. And then '29 come and the same thing happened and he said, 'Well that was a quadrella then. You had the dust and the erosion and the wind, as 
well as the rabbits, as well as there'd been a mouse plague from the good harvest of ' 28 , and then the Depression hit.'

So, yeah, that tested people out. I mean, if you stayed in the Mallee then, you were serious. [grins] ${ }^{37}$

Indeed, the triumphalism of Mallee land settlement abated in the 1930s when, amid economic strife, the region experienced dust 'monsters' attributed to massive land clearance, soil tillage and drought. ${ }^{38}$ As Griffiths writes, 'Many farmers were overwhelmed by this environmental disaster, and families abandoned their homes and holdings in the middle of the night, unable to face the neighbours who stayed'. ${ }^{39}$ That experience of disaster wrought an era of public and bureaucratic concern over environmental problems, culminating in the establishment of the Soil Conservation Board in 1940.40 Meantime, in the press, Mallee, dust, salt and wind came to form the discursive markers of a counter-narrative of colonial presence. 'Is the Mallee Blowing Away?' posed a headline in The Australasian in January 1941, for example. ${ }^{41}$ Mallee soils had been 'badly treated' by settlers, that report cited: overstocking with sheep and cattle, rapid expansion of land cultivation, 'bad seasons' and government advice to 'grow more and more wheat' had all contributed to unprecedented soil drift. With 'millions of taxpayers' funds sunk in the ruins', Victoria was in jeopardy of becoming 'a menacing dust bowl'. ${ }^{42}$ The Mallee, as both physical and cultural site, was being constructed as having fallen victim to processes of excess through a 'lexicon of consequence'-which, as cultural historian J. M. Arthur has pointed out, is how problems associated with dust, wind and salt have been represented in dominant Australian discourse on environment. ${ }^{43}$

The notion that environmental destruction could be pinned on an ignorant people was an inadequate summation of settler regard for the land or knowledge of its limits, however. As historian Worster argued in his history of the American Dust Bowl-Depression era, which, similarly, spanned the 1930s, capitalism has been a decisive factor in agricultural exploitation: 'We speak of farmers and plows on the plains and the damage they did,' he wrote, 'but the language is inadequate. What brought them to the region was a social system, a set of values, an economic order. ${ }^{44}$ Further, as Tim Bonyhady argued in his episodic work of Australian environmental history, The Colonial Earth, people can know much about land-and 
still damage it. Bonyhady advocated a more complicated version of the past, for 'it was largely through the detail of what Australians depicted, said, and did that one could see how they occupied the land, both imaginatively and physically'. ${ }^{45}$ On that note, Sheldon's retelling of this period of Mallee history-a mediation of lived experience-sentimentalised the value of backbreaking labour and of family and community endurance. This served, as we shall see, as both cultural capital and an historical backdrop for change, if localised redemption.

Sheldon's story of 'Mallee survival' continued through an agricultural cycle of boom and bust: where the 1930s were 'reasonable seasons', in the 1940s drought returned; in the drought of 1944, there was some erosion again, but that 'broke' in the start of 1945 and 'the weather pattern opened up' once more. ${ }^{46}$ From the late 1960s, Sheldon's history shifted into an era of personal recollection-of what he remembered 'in his time'. Dust storms marked his recollection of the drought of 1967: 'I was only a little kid, I can remember a coupla paddocks here blew a bit.' ${ }^{47}$ And then, 'o'course', he said, he couldn't forget the summer of 1983. As connoted, drought in the early 1980s came to be viewed as a defining period for dryland agriculture in the Mallee, when socioeconomic hardship peaked. Widespread crop failure, declining world prices for wheat and, significantly, skyrocketing interest rates combined to create 'a most difficult period' for debt-laden Mallee farmers and farm communities. ${ }^{48}$ Farm livelihoods crumbled. Families, marriages and individual lives 'fell apart'. A throwaway line in a 1989 report by the University of New England's Rural Development Centre indicated the degree of human despair: 'Given the situation in the Mallee [by] late 1985, virtually any action taken would have led to some improvement in the community's wellbeing.' ${ }^{9}$ And, as Sheldon's story reveals, the 1980s drought came to signify not only Mallee crisis but also an environmental battleground:

It looked shocking, you know, at the end of February [1983] and you were wonderin' how much worse is it gonna get. I mean a lotta paddocks that were pasture were gouged out in strips, where sheep had walked ... looked like there'd been a war fought there. ${ }^{50}$

Here Sheldon's story represents a connection between war and drought discourses in dominant rural history of the Mallee (a site of 'battle with nature' by no means 
exclusive to drought; as Don Garden wrote in his history of the state of Victoria: 'Man did not gain an upper hand in the Ninety Years War against the rabbits until the $\left.1950 s^{\prime}\right) .{ }^{51}$ More broadly, Australian histories of drought-affected landscapes have attracted not only militarist discourse but also military historians, with one of the most prominent social histories of drought in Australia having been compiled by Michael McKernan, a former senior Australian War Memorial historian. And, as he confessed in the introductory pages to that history, Drought: The Red Marauder, he was drawn to study drought after he came across a poignant remark from a Mallee soldier settler on drought during the Depression: 'I would sooner do ten years at the war than one at the Mallee. ${ }^{52}$ If drought in our national history has come to function as a key symbol in a 'white Australian mythology' — as sociologists Brad West and Philip Smith contend, 'to temper the national character through struggle'-then dominant Mallee histories have read as stories of over-riding heroism, if not victory against all odds. ${ }^{53}$

—UNCERTAINTY

I think that maybe some of the farmers are really frightened ... They're struggling now to try and keep their heads above water financially and ... they don't want to hear more doom and gloom ... While there's 'doubt' there about global warming, they'll take it.

Lynne Healy, women's health worker, $2006^{54}$

There's doubt starting to come into it, whether it's really worth doing what we're doing. Because really, if it-the drought of '06-happens again in '07, I would pretty confidently say ... the age group of between 25 and 35 probably won't be here in two years.

Brent Morrish, harvesting contractor/conventional broad-acre wheat farmer, 200755

Social anthropologists on several continents and in varied cultural contexts have argued that lived experience, and the memory of it, strongly shapes farmers' interpretations of climate. ${ }^{56}$ As one study into how farmers used local and scientific information on climate concluded, farmers' interpretations were 'anchored in their remembrance of desirable or dreaded situations they lived through, their 
observations about the conditions that brought them about, and their assessments of how they managed through them'. ${ }^{57}$ Sheldon's oral history lends plenty of weight to that precis-most significantly, perhaps, when his story drifted from past to present, when he began to depict the experience of dwelling in agro-industrial uncertainty. Arguably, in the late twentieth century Australian farmers became 'chained' to a treadmill of corporate dependency, technological change and productivism. ${ }^{58}$ Geographer Geoffrey Lawrence has pointed to the use of chemicals in agriculture as a prime example of this. He writes: 'the faster chemicals are applied, the more they will be needed in the future: the faster agriculture utilises the corporate strategy of agribusiness, the greater the entire community's reliance upon that strategy and upon those corporations becomes'. ${ }^{59}$ Lawrence noted the 'illogical' foundations on which that strategy was based, including its dependency on nonrenewable resources (fossil fuels) and its potentially damaging impacts on food products, the people who eat them, and the agricultural ecosystem producing them too. 60

Sheldon's narrative of his life on the land produced a troubling contemplation of this 'agricultural modernity', of the rise of intensified and monocultural cereal cropping practices, aided by modified crop breeds and a nearautonomous technological advance. Further, talking about this era prompted a reflexive assessment of the dependency of agricultural communities on the conditions of the production treadmill, that is, of how such dependency had reshaped drought 'survival'. And, at this point of Sheldon's story, historical awareness of the harmful impacts of agri-capitalism upon the Mallee environment was expressed as a desire to learn how to read country better-for, as environmental historian Richard White wrote: 'A connection with the land through work creates knowledge, but it does not necessarily grant protection to the land itself.' 61

In the decade to 1985, the Sheldons had cropped some of their ground 'hard'.62 Through soil tillage, or 'working the ground' on a system of 'good early fallow', Sheldon said his father 'could tend to be a little bit over-keen': 'He used to get it driftin' - there's no denyin' that.'63 When his father passed away, Sheldon had turned twenty-five. 'I've just stayed with the four-square mile o' land that we hadthere's roughly 2500 acres [about 1000 hectares]-and stayed with simple 
machinery from mid-1960s'.64 That said, the property was to undergo significant change under Sheldon's new 'management'. He started experimenting with ways to get clover, which had been farmed, fallowed and sprayed out over the years, back into his paddocks for soil health. ${ }^{65}$ Then he began to look into chemical-free farming. 'I read a little book about organics at the beginning of '92,' he said. 'A few things in that little book ... twigged the imagination a bit and I thought well, you know, I'll have a go at this.' 66 Sheldon said he began to rethink his farm as part of an ecosystemic whole. In the context of his shift to organic agriculture, he portrayed uncertainty over the sustainability of conventional dryland farming. In that portrayal, not only were dominant agricultural monocultures destroying the conditions for diverse species to exist; dominant knowledge was destroying the very conditions for alternatives to exist.

First, he realised he had to 'slow it down': his ideas of sustainability were embedded in discourse on 'easing off' and 'pulling back'. This was a decline narrative of decelerating progress to create a more environmentally sound agriculture. This version of an antimodern environmental declinism was founded upon questioning the speed, size and intensity of modernising processes (techno-scientific activity) in late capitalist agriculture.67 It also questioned scale and complexity in place and identity-making processes. 'The only way things can really get back to how it could be sustainable?' Sheldon proffered: 'You gotta have smaller holdings with people that are really interested in what they're doing.' ${ }^{68}$ In contrast to contemporary, prevailing, neoliberal discourse of agricultural and economic vulnerability that focuses on issues of scale (smaller farms are considered more vulnerable to the hazards of climate, much as global economic forces are perceived increasingly as determining futures for local people) Sheldon advocated 'smallness' in agricultural holdings and machinery, and 'simplicity as best'. 69

Sheldon explicitly linked the increased use of chemicals in agriculture to technological change that superseded human labour, thus, to the loss of social capital in the Mallee. Sheldon pointed out what he'd heard was happening in the Western Australian grain-belt. There, earlier than in northwest Victoria, farmers had taken on zero-tillage practices-a way of growing crops from year to year without disturbing the soil through tillage, thus increasing the amount of water in the soil, 
decreasing erosion and yet, paradoxically, significantly increasing herbicide usage as a means to adapt to drier climatic conditions:

A lot of farmers around here are going zero-till and all spraying [herbicides]. That'll run its course. The system's breaking down in Western Australia now already ... They're going back to tillage. A lot of damage will be done in the meantime. ${ }^{70}$

While agri-scientific expertise and farming lived experience were considered both valid but inherently partial in the formation of a broader social-environmental knowledge, Sheldon believed the widespread shift toward zero-tillage practices (which are currently advocated by farming soil conservation groups, backed by state and federal government funding, as a key means of achieving greater agricultural sustainability in the Mallee) by conventional farmers was effectively 'replacing people with a boom spray'. 'We want to keep it simple and keep some people in the district,' he said, 'rather than just get bigger.'71

Thus, Sheldon historicised the rise of agricultural science and technology in terms of community decline and the de-industrialisation of agricultural practices, countering the capacity of capitalism to reconstruct landscapes as exchange values under profit imperatives. 'The "get big or get out" era', he said of the late twentieth century, was when 'real change' occurred in the Mallee: 'Many of the early farmers got out then.' And farms did get big-up to twenty thousand acres, in parts. Meanwhile, however: 'All your small clubs, whole community, falls to bits ... It's the old story: if you keep replacing people with machinery, don't need any people eventually. ${ }^{72}$

In the meantime, based on his assessment of environmental risk, Sheldon had sought to reduce and eventually eliminate his dependence on the chemical materials of mainstream agriculture. From this emerged a perception of social risk and a communitarian aim-of strong communities amid uncertainty-that was premised on nostalgic renditions of a more populated rural past. This implied that some more mutualistic, cooperative (mythic) version of community existed prior to the 'get big or get out' era of the preceding three decades, as agricultural 'restructuring' reshaped the Australian countryside. Driving this vision of a 'return' to bigger rural communities was that of going 'back' to greater reliance upon human labour. Also, this stressed the significance of dwelling in meaningful work, which 
critically framed Sheldon's ideas on agricultural sustainability in the Mallee-and circumscribed his vision of a Mallee future under conditions of climate change. Indeed, Sheldon's Mallee was 'a forgiving style of landscape'-one that required people's respect, and of which humans should avoid asking 'too much':

What I mean by 'forgiving': you can't belt your country and expect it just to come back. And when I say 'belt it': crop it and crop it and crop it and expect it to keep giving ... the country can look fairly crook after a prolonged period of dry weather, but you don't need huge amounts of rainfall for this country to really blossom ... It's good country as long as you work within the limits of what it can do. ${ }^{73}$

-ADAPTATION

We are more culturally determined to not be satisfied with stopping ... It's a kind of grotty Darwinian way to think about things ... It's a global problem that requires economic engineering ... I can see so many signs of human evolution at work in the economy and so many signs of economy in human evolution.

Ben Jones, farm consultant/research agronomist, $2007^{74}$

Well no ... we can't let it [climate change] become a negative. We've always got to learn. You've got to see and adjust as you go along.

Jim Maynard, Mallee Sustainable Farming chairman/ conventional broad-acre wheat farmer, $2007^{75}$

The spring of 2006, in particular, brought a dramatic shift in Australian discourse on climate, which was linked to Australians' contemporary experience of the weather and underlined the power of popular culture as a medium for mainstream science. ${ }^{76}$ By 2007, as a survey of Australian attitudes to climate change reported, the 'vast majority' of Australians no longer doubted climate change was 'real' or attributable to human activity that caused greenhouse gases. ${ }^{77}$ The report concluded: 'Water shortages and the drought have certainly sharpened the public's interest in the issue and a sense that we are already seeing the effects of climate change. ${ }^{78}$ In Sheldon's view too, local climate was shifting in ways that defied lived experience: 
Do you believe in climate change?

I think it's different than what it was ... [last year we] had four exceptionally cold, windy days at the start of February, and that's the first time I'd ever seen that happen in my life ... I can remember back as far as when I was a kid, I mean, the first or second week of February was always back at school, and it was stinkin' hot ... We did not have cold southerlies and that sorta weather in the ' 60 s and the ' 70 s ... or in the ' 80 s for that matter. ${ }^{79}$

Yet to Sheldon, farming in the Mallee was an ongoing 'learning experience'. As one of more than fifteen hundred certified organic farms in Australia, which covered about 1.7 per cent of Australia's agricultural area in $2003,{ }^{80}$ his home formed a site of possibility-not for the kind of growth, development or risk-taking manifest in dominant agri-capitalist outlooks, but for renewing relations to place. In light of climate change, rather than seek a technological fix, he stressed the need to keep learning to 'adapt yourself and your lifestyle to that country, and try and get a consistent pattern year after year':

That's the critical balance that I feel that we do need to really learn as dryland farmers in the country, is what we can do over a long period and not have to think: 'Oh well, we've had a drought, we've gotta crop the whole lot next year and hope like hell we get a big season to get outta trouble.' It's a bit like anything in life-if you can get consistency into your pattern, you'll go a lot further than having boom or bust all the time. ${ }^{81}$

It was in that context of conditions under climate change that Sheldon envisioned the future:

We're probably gonna have to change the way we do things sooner rather than later. And once again, it'll be something that'll have to be done at an individual level ... It'll be a new generation of pioneers, roughly. We won't have to clear the land and work with horses and bust our guts, but ... we'll have to ... have a modest lifestyle and be prepared to put a fair bit of what your farm makes back into changing it. That's the only way it'll happen. ${ }^{82}$

Here discourses of endurance, uncertainty and adaptation appear to collide. This was an interpretation of farming environment in which climatic uncertainty and 
pioneering struggle served as defining features, which proffered a means of 'adapting' to a changing Mallee climate-where tradition helps constitute renewal. In this regard, his was a political (moral) discourse of observing socialenvironmental 'limits', and of revaluing labour in the relations of nature and livelihood. Concurrently, that interpretation of life under conditions of climate change served to amplify a local identity- and place-based discourse of Mallee hope and endurance. Anchored in remembrance of droughts, and the assessment of having managed to endure, Sheldon's discourse on 'climate change pioneers' returned to drawing upon settler-descendent cultural capital-a collective history of survival.

The cultural renegotiation of climate is tied to the imagining of landscapes; conversely, as this article argues, the historical discursive delimitation of drought has been every bit material as it has been consequential. Sheldon's story, an account of the experience of dwelling in uncertainty, formed an active reconstruction of the past in a bid for renewal-a compelling bid to retraditionalise a social environment that drew attention to existential crisis as rural change (socio-economic, structural, political and environmental) posed a threat to the identity of Mallee dryland farming people. ${ }^{83}$ Certainly, insofar as this paper sheds light on an affirmation of and challenge to a narrative of rural 'pioneering' in light of climate change, drought discourses attest to the power and pervasiveness of battler histories of endurance in Australian rural culture. Perhaps in some respects, however, perceptions of climate change (globalist ideas per se) are complicating the very idea of 'droughts' having an end (or a beginning). Yet a survivor narrative does assume a stable self can be recovered. In the face of change, Sheldon's oral history conjured a grand narrative of cultural and physical processes acting together to determine or block the path to survival. His ideas represented a form of resistance, founded on principles of mutual aid, simplicity, direct action and decentralisation, and his organic farm 'plan' was a kind of limited farming 'utopia of reconstruction' that sought to renew specific, creative relationships between humans and non-humans. ${ }^{84}$ His story began to touch upon the formation of a biological model, a lesson in environmental history. In the end, Sheldon's story was about an Australian environment and his changing 
relationship to it, his conversation with it, if you will, as much as it was about a collective conversation:

When you look at Australia and its history ... while we've been here a coupl'a hundred years, we've probably only really developed the country in the last hundred, and more particularly in the last fifty. So that's a very, very brief time. And we've altered this landscape a hell of a lot in a short period o' time.

And if that's gonna change our weather patterns-which it, well, it looks like it is-we need to look at what we've done in the past and try and learn. 85

Deb Anderson's interests lie in rural, environmental and cultural studies. She is working on a PhD at the University of Melbourne; she also works for the press. Deb lives in the city's political greenbelt but home is still the family farm on which she grew up, in the sticks of north Queensland.<deanderson@theage.com.au>

\section{-ACKNOWLEDGEMENTS}

This research was conducted on project sponsored by the University of Melbourne and Museum Victoria. The author wishes to thank Hubie Sheldon, whose stories form the core of this paper, CSR editors and referees for their comments, and Wendy and David Anderson, Aneta Podkalicka and Tom Bamforth for a wealth of ideas and encouragement.

\section{-NOTES}

1 James O'Connor, The Meaning of Crisis: A Theoretical Introduction, Basil Blackwell, Oxford, 1987, p. 13. 2 Sociologists wrote of the 'cliché' of rural crisis coverage in Lisa Bourke and Stewart Lockie, 'Rural Australia: An Introduction', in Stewart Lockie and Lisa Bourke (eds), Rurality Bites: The Social and Environmental Transformation of Rural Australia, Pluto, Sydney, 2001, pp. 1-13, p. 1.

3 The first and second quotes are derived from Deb Anderson, 'Hubie Sheldon: Perceptions of Climate Change in the Mallee', unpublished oral history, Ngallo, Vic., 2006. The third quote is from Deb Anderson, 'Hubie Sheldon: The Lived Experience of Drought in the Mallee', unpublished oral history, Ngallo, Vic., 2005. As yet unpublished, all of the oral histories recorded for this research will form a new collection and state resource at Museum Victoria (expected to become available in 2010). 4 Barbara Adam, 'Detraditionalisation and the Certainty of Uncertain Futures', in Paul Heelas, Scott Lash and Paul Morris (eds), Detraditionalisation: Critical Reflections on Authority and Identity, Blackwell, Oxford, 1996, pp. 134-48, p. 137. 
${ }^{5}$ Worster argued Darwinism had turned biology into history, such that a story of 'change' became that of progress in nature. Donald Worster, 'Nature and the Disorder of History', in Michael Soule and Gary Lease (eds), Reinventing Nature: Responses to Postmodern Deconstruction, Island Press, Washington, DC, 1995, pp. 65-85, 69-70.

6 See, for example, Sheldon Krimsky, 'The Role of Theory in Risk Studies', in Sheldon Krimsky and Dominic Golding (eds), Social Theories of Risk, Praeger, Westport, Connecticut, 1992, p. 20.

7 The project began in 2003. Initially, I intended to end the fieldwork phase in the summer of 2005. By that autumn, however, about half of Australia's arable land was drought-affected. Declarations of drought and government announcements that those afflicted would receive social welfare 'relief payments' made national news headlines on a near-daily basis. As the dry conditions lingered, the historical and meteorological record books were rewritten. This prompted a second round of fieldwork in February 2006, and a round of brief follow-up interviews in 2007.

${ }^{8}$ Brad West and Philip Smith, 'Drought, Discourse and Durkheim: A Research Note', Australian and New Zealand Journal of Sociology, vol. 32, no. 1, 1996, pp. 93-102, 94. West and Smith conducted their study of media and political texts over the one hundred years to 1995.

9 John Howard in Misha Schubert, '\$250m Rescue Package for Farms', Age, 31 May 2005, p. 4.

10 Deb Anderson, 'Drought, Endurance and "The Way Things Were": The Lived Experience of Climate and Climate Change in the Mallee', Australian Humanities Review, no. 45, 2008, pp. 67-81.

11 When I returned to the Mallee in 2006 and 2007, talk of uncertainty about climate change peppered discussion on drought. The interviewees began reflecting on their earlier observations. Some doubted themselves. Others doubted the climate science. All doubted the politicians who had weighed in heavily on climate change debate as a federal election year drew closer. Interviewees were reconciling knowledge of climate gained through lived experience with more abstract ideas received through science and the media.

12 I initially used contacts established by Museum Victoria to locate potential subjects in August 2004. Thereafter, I located interviewees through 'cold calling' or by referral from initial interviewees. I sought a cross-section of perspectives from people in a number of industries and public services. This resulted in a group of twenty-two interviewees, who typically wore several 'hats' in life: farmers, home-makers, members of local government, harvesting contractors, a newspaper editor, a nurse, women's health workers, educators, administrators, agronomists and people involved in community-driven organisations dedicated to social and environmental sustainability, social welfare advocacy and the preservation of local history. Most interviews were recorded and conducted face-to-face, on average once a year for three years.

${ }^{13}$ Anderson, 'Drought, Endurance and "The Way Things Were"'.

14 Mick Lumb, 'Introduction', in David Connor and David Smith (eds), Agriculture in Victoria, Australian Institute of Agricultural Science, Melbourne, 1987, p. 5.

15 The Victorian Mallee (representing 17.3 per cent of Victoria's total area) is but a portion of Australian Mallee country. The semi-arid region also covers parts of New South Wales and South Australia, and extends across the Nullarbor through Western Australia. As such, the Mallee demarcates the edge of the Australian commercial cropping zone.

16 Mallee Catchment Management Authority, 'Region Profile', 2008, viewed 10 March 2008, at <http://www.malleecma.vic.gov.au/index.php?id=66>. Farmers also crop barley, field peas, canola, oats, rye, corn, lupins and other pulses.

17 Department of Primary Industries Victoria, 'Mallee: Climate', 2007, viewed 14 February 2008, at <http://www.dpi.vic.gov.au/dpi/vro/malregn.nsf/pages/mallee_climate>.

18 Tom Griffiths, 'Mallee Roots: A Brief History of Victoria's Northwest', Park Watch, no. 178, 1994, pp.

21-3, p. 21. 
${ }^{19}$ Rhona van Veldhuisen, Pipe Dreams: A Stroll through the History of Water Supply in the WimmeraMallee, Wimmera-Mallee Water, Horsham, Victoria, 2001, cover. See also, for example, Doris Torpey, The Way It Was: A History of the Mallee 1910-1949, Local History Resource Centre, Ouyen, Victoria, 1986 and Weston Bate, Having a Go: Bill Boyd's Mallee, Museum Victoria, Melbourne, 1989.

20 Winifred M. Nixon, While the Mallee Roots Blaze: The Story of Berriwillock, Back to Berriwillock Committee, 1965, Berriwillock. Chapter One of Nixon's work begins: 'I came, I saw, I conquered'. See also: Back to Berriwillock Committee, Foreword, Berriwillock Centenary, Mallee Printers, Sea Lake, 1990, pp. 5-6.

21 Don Hopgood, Foreword, in J. Noble, P. Joss and G. Jones (eds), The Mallee Lands: A Conservation Perspective, CSIRO Australia, Adelaide, 1989, p. v.

22 CSIRO and Australian National Botanic Gardens, 'Habit', Euclid, 2002, viewed 15 August 2009, at <http://www.anbg.gov.au/cpbr/cd-keys/Euclid/sample/html/habit.htm>.

23 D. Parkes and D. Cheal, 'Perceptions of Mallee Vegetation', in J. Noble, P. Joss and G. Jones (eds), The Mallee Lands: A Conservation Perspective, CSIRO Australia, Adelaide, 1989, p. 7; J. M. Arthur, Default Country: A Lexical Cartography of Twentieth Century Australia, UNSW Press, Sydney, 2003, pp. 91-5. ${ }^{24}$ See, for example, Margaret Kelly, Discover Victoria's Mallee: Experience the Heritage and Explore its National Parks, Margaret Kelly, Meringur, Vic., circa 1992, p. 5.

25 That marker refers to the country situated between temperate woodlands to the south and more arid flora to the north; see Hopgood, Foreword, p. v.

26 Griffiths, 'Mallee Roots', p. 23.

27 Anderson, 'Sheldon: The Lived Experience of Drought'.

${ }^{28}$ Jill Nickolls and Ann Angel, Mallee Tracks: A Wanderer's Guide to the South Australian and Victorian Mallee, Jill Nickolls and Ann Angel, Pinnaroo, SA, 2003, p. 86.

29 Kenyon, cited in Robin Bromby, Unlocking the Land: The Saga of Farming in Australia, Lothian, Melbourne, 1986, p. 55.

30 The first Kenyon quotation is in Bromby, Unlocking the Land, p. 55. The second, Alfred Kenyon, The Story of the Mallee: A History of the Victorian Mallee, Read Before The Historical Society of Victoria 18 March 1912, Ian Wood and Keith Hofmaier, Rainbow, Vic., 1982, pp. 1-2.

31 Deb Anderson, 'Robert, Merle and Michael Pole: The Lived Experience of Drought in the Mallee', unpublished oral history, Walpeup, Vic., 2005.

32 Deb Anderson, 'Andrea Hogan: The Lived Experience of Drought in the Mallee', unpublished oral history, Hopetoun, Vic., 2005.

33 Deb Anderson, 'Greg Brown: The Lived Experience of Drought in the Mallee', unpublished oral history, Underbool, Vic., 2005.

34 Anderson, 'Sheldon: The Lived Experience of Drought'.

35 His father began keeping rainfall records for the property in 1954. Anderson, 'Sheldon: The Lived Experience of Drought'.

36 Anderson, 'Sheldon: The Lived Experience of Drought'.

${ }^{37}$ Anderson, 'Sheldon: The Lived Experience of Drought'.

38 Griffiths, 'Mallee Roots', p. 22.

${ }^{39}$ Griffiths, 'Mallee Roots', p. 22.

40 Griffiths, 'Mallee Roots', p. 23.

${ }^{41}$ R. V. B., 'Drifting Sands: Is the Mallee Blowing Away?' The Australasian, 18 January 1941, pp. 42-3, 42.

42 R. V. B., 'Drifting Sands', pp. 42-3.

${ }^{43}$ Arthur, Default Country, p. 162.

44 Donald Worster, Dust Bowl: The Southern Plains in the 1930s, Oxford University Press, Oxford, 1979, pp. 4-5. 
45 Tim Bonyhady, The Colonial Earth, Melbourne University Press, Melbourne, 2000, p. 2.

${ }^{46}$ Anderson, 'Sheldon: The Lived Experience of Drought'.

47 Anderson, 'Sheldon: The Lived Experience of Drought'.

${ }^{48} \mathrm{Jim}$ Lees, Bruce McKenzie, Nick Jackson and Jennifer Greaney, The Mallee Crisis Committee Experience:

A Review, Rural Development Centre, Armidale, NSW, 1989, p. 1.

49 Jim Lees et al., The Mallee Crisis Committee Experience, p. i.

${ }^{50}$ Anderson, 'Sheldon: The Lived Experience of Drought'.

51 Don Garden, Victoria: A History, Thomas Nelson Australia, Melbourne, 1984, p. 131.

52 In Michael McKernan, Drought: The Red Marauder, Allen \& Unwin, Sydney, 2005, p. 3.

53 West and Smith, 'Drought, Discourse and Durkheim', p. 99.

${ }^{54}$ Deb Anderson, 'Gwen Cooke and Lynne Healy: Perceptions of Climate Change in the Mallee', unpublished oral history, Ouyen, Vic., 2006.

55 In Deb Anderson, 'Brent and Melissa Morrish: Perceptions of Climate Change in the Mallee', unpublished oral history, Tiega, Vic., 2007.

56 See, for example, Sarah Strauss and Benjamin Orlove (eds), Weather, Climate, Culture, Berg, New

York, 2003.

${ }^{57}$ Carla Roncoli, Keith Ingram, Christine Jost and Paul Kirshen, 'Meteorological Meanings: Farmers Interpretations of Seasonal Rainfall Forecasts in Burkina Faso', in Strauss and Orlove (eds), pp. 181200.

58 See, for example, Geoffrey Lawrence, Capitalism and the Countryside: The Rural Crisis in Australia, Pluto, Sydney, 1987; Lockie and Bourke (eds), Rurality Bites; Ian Gray and Geoffrey Lawrence, A Future for Regional Australia: Escaping Global Misfortune, Cambridge University Press, Cambridge, 2001.

${ }^{59}$ Lawrence, Capitalism and the Countryside, p. 62.

60 Lawrence, Capitalism and the Countryside, pp. 62-3.

${ }^{61}$ Richard White, 'AAre You an Environmentalist or Do You Work for a Living?": Work and Nature', in William Cronon (ed.), Uncommon Ground: Rethinking the Human Place in Nature, W. W. Norton \& Co., New York, 1995, pp. 171-85, 181.

62 For example, some paddocks were cropped continuously for up to four years.

63 Anderson, 'Sheldon: The Lived Experience of Drought'.

64 Anderson, 'Sheldon: The Lived Experience of Drought'.

${ }^{65} \mathrm{He}$ spread gypsum and toyed with different rates of nitrogen fertiliser and trace elements.

${ }^{66}$ Anderson, 'Sheldon: The Lived Experience of Drought'.

${ }^{67}$ Andrew Murphy has analysed the family of critiques known as antimodern environmental declinism as part of a longstanding rhetorical tradition of decline narratives. See Andrew Murphy,

'Environmentalism, Antimodernism, and the Recurrent Rhetoric of Decline', Environmental Ethics, vol. 25, no. 1, 2003, pp. 79-98.

68 Deb Anderson, 'Hubie Sheldon: Update', telephone interview, Ngallo, Vic., December 2007.

${ }^{69}$ Anderson, 'Sheldon: Update'.

70 Anderson, 'Sheldon: Update'.

71 Deb Anderson, 'Hubie Sheldon: Reflections on Drought and Climate Change', unpublished oral history, Ngallo, Vic., February 2007.

72 Anderson, 'Sheldon: Update'.

73 Anderson, 'Sheldon: The Lived Experience of Drought'.

${ }^{74}$ Deb Anderson, 'Ben Jones: Reflections on Drought and Climate Change', unpublished oral history, Mildura, Vic., 2007.

75 Deb Anderson, 'Jim Maynard: Perceptions of Climate Change in the Mallee', unpublished oral history, Mildura, Vic., 2007. 
${ }^{76}$ Scientist Snow Barlow cited in Nerissa Hannink, Rebecca Scott and Janine Sim-Jones, 'The Big Shift', University of Melbourne Voice, vol. 1, no. 1, 2007, p. 4. 'The record maximum temperatures and the accompanying bush fires of early spring 2006 dramatically underlined to the community that this is not just a severe drought-it is climate change,' Barlow wrote. Significantly, he added: 'At the same time we had the Stern report providing credible economic analysis of the costs of continued inaction and $\mathrm{Al}$ Gore's Oscar-winning "slide-show" bringing the science of climate change to millions in Australia and internationally.'

77 The Australian Climate Institute (whose stated goals, it should be noted, were to raise awareness of global warming and 'motivate the country to take positive action') reported in March 2007 that concern about climate change was at 'an all time high', after a survey of 1000 Australians found that climate change ranked as more important than housing affordability and national security. See Climate Institute of Australia, 'Climate of the Nation: Australians' Attitudes to Climate Change and its Solutions', 31 March 2007, viewed 18 May 2007, at

$<$ http//www.climateinstitute.org.au/cia1/publication.php?content_id=80>, pp. 1, 3.

78 Climate Institute of Australia, 'Climate of the Nation', p. 17.

${ }^{79}$ Anderson, 'Sheldon: Perceptions of Climate Change'.

${ }^{80}$ About 14 per cent of certified organic farmers produced cereal crops in 2003. Commonwealth Department of Agriculture, Fisheries and Forestry, 'The Australian Organic Industry: A Summary', 2004, viewed 15 August 2009 at <http://www.daff.gov.au/foodinfo>. The foreword to this report stated that, as yet, little data was published on the organic industry in Australia.

81 Anderson, 'Sheldon: The Lived Experience of Drought'.

82 Anderson, 'Sheldon: Perceptions of Climate Change'.

83 Anderson, 'Drought, Endurance and "The Way Things Were"'.

84 David Macauley, 'Introduction: Greening Philosophy and Democratising Ecology', in David Macauley (ed.), Minding Nature: The Philosophers of Ecology, Guildford, New York, 1996, p. 6. Macauley used the term to trace the emergence of philosophical work that illuminated the ecological dimensions of utopian thought. Specifically, he used the term to distinguish philosopher Lewis Mumford's work on utopia from that which focused on 'escape'.

85 Anderson, 'Sheldon: The Lived Experience of Drought'. 